\title{
Implikasi RAPBN 1992/93 Terhadap Sukư Bunga
}

\author{
Oleh : Sutrisno
}

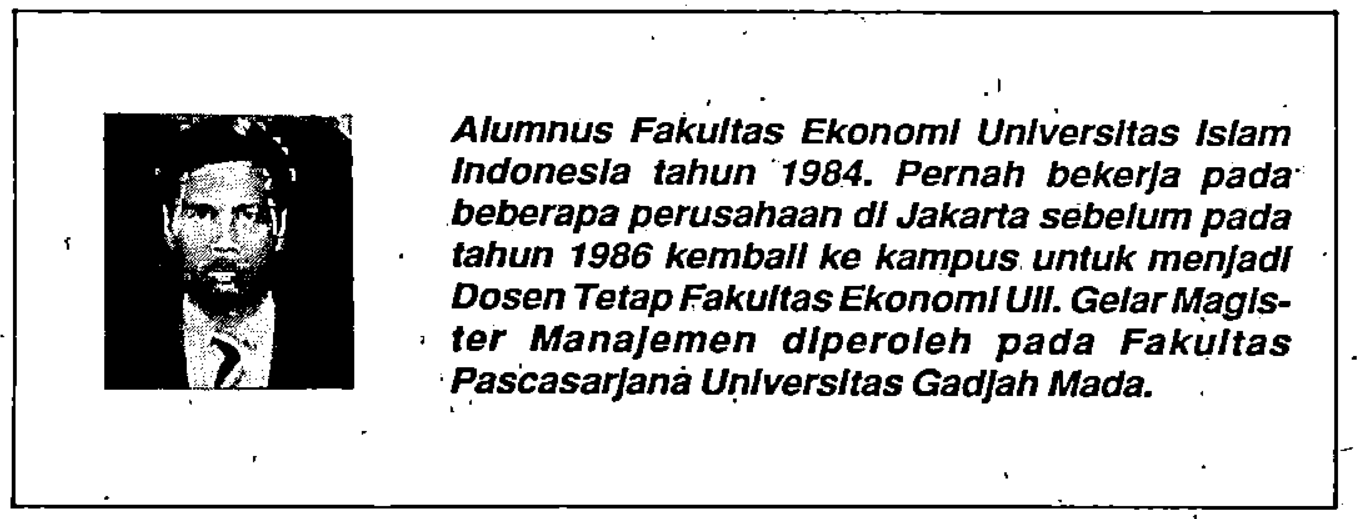

Pendahuluan

Mèrupakan suatu kelaziman bahwa sejak pemerintahan Orde Baru, setiap awal tahun pemerintah menyampaikan rencana anggaran pendapatan dan belanja negara (RAPBN). Hal ini sebagai manifestasi dari pasal 23 Undang-undang Dasar 1945. Bersama dengan pengajuan rencana anggaran tersebut Presiden selaku kepala pemerintahan menyampaikan nota pengantar RAPBN yang merupakan usulan pëmerintah kepada DPR untuk mendapat pertimbangan dan persetujuan.

Pada tahun ini RAPBN 1992/1993 telah disampaikan oleh Presiden Soeharto pada tanggal 6 Januari 1992, yang isinya cukup realistik, dalam arti telah mempertimbangkan perkembangan keadaan, kendala yang akan dihadapi serta peluang yang terbuka dan dapat diharapkan.

Dengan adanya pengalaman maśa lalu yang menunjukkan bahwa APBN disusun dan dilaksanakan berdasar prinsip berkembang dan berkesinambungan menuju kearah kemandirian, sehingga telah memberi corak khusus yang mencerminkan adanya tekad pemerintah untuk meningkatkan pembangunan dan kesejahteraan masyarakat secara berkelanjutan. Perkembangan APBN selama ini memberikan gambaran secara nyata bahwa tekad pemerintah untuk meningkatkan pembangunan dan kesejahteraan dimanifestasikan pada 
semakin besarnya alokasi dana pembangunan dari tahun ke tahun. Demikian pula pada RAPBN 1992/1993 yang besarnya mencapai Rp 56,1 trilyun. Jumlah alokasi pengeluaran pembangunan meningkat dari sekitar Rp 20 trilyun menjadi kurang lebih Rp 23 trilyun.

Memang telah disadari oleh berbagai kalangan bahwa dalam menyusun RAPBN 1992/1993, pemerintah banyak menghadapi tantangan yang tidak ringan, baik yang berasal dari dalam negeri maupun luar negeri. Dari dalam negeri -misalnya, kondisi ekonomi dan moneter yang terjadi séláma tahun 1991 diperkirakan kurang memberikan dukungan positif terhadap pencapaian berbagai sasaran penerimaan, sedangkan. penerimaan pembangunan yang notabene seluruhnya berasal dari pinjaman luar negeri, juga menghadapi kendala karena beberapa negara donor seperti IGGI bersikaf kurang positif yang disebabkan adanya Insiden Dili.

RAPBN 1992/1993 dibandingkan dengan APBN 'tahun-tahun sebelumnya bisa dikatakan sebagai anggaran yang kontraktif. APBN tahun-tahun sebelumnya selalu bersifat ekspansif yang ditandai dengan membanjimya kredit likuiditas. Sedangkan RAPBN mendatang justru serba ketat.

Karena sifatnya yang kontraksi tersebut, maka RAPBN 1992/1993 tentu saja juga akan banyak menimbulkan implikasi yang luàs bagi perkembangan ekonomi. Implikasi ini tentunya juga akan menimpa dunia perbankan dalam menentukan tingkat sukubunganya.

Faktor yang Mempengaruhi Suku Bunga

Besar kecilnya suku bunga, baik sukubunga simpanan atau deposito maupun sukubunga kredit sangat dipengaruhi oleh beberapa faktor, baik faktor ekstemal maupun intemal.

Faktor eksternal yang mempengaruhi tinggi rendahnya sukubunga adalah:

1. Keadaan Ekonomi dan keuangan nasional

Dalam konteks ini adalah suatu kondisi yang berhubungan dengan tingkat penawaran dan permintaan akan uang, dimana pada akhirnya akan berpengaruh terhadap inflasi dan suku bunga. Sebagai ilustrasi dapat dilihat dalam contoh berikut, bank cenderung untuk menaikkan sukubunga depositonya bila penawaran masyarakat akan dana rendah, sehingga untuk mengantisipasi keadaan semacam itu bank merangsang dengan tingkat bunga deposito yang lebih.tinggi agar masyarakat berminat mendepositokan uangnya. Begitu juga sebaliknya, jika penawaran' dana oleh masyarakat tinggi, maka bank cenderung untuk menurunkan tingkat bunganya untuk menekan beban bunga yang harus ditanggung oleh bank jika masyarakat mendepositokan uangnya pada bank.

2. Kebijaksanaan pemerintah

Dalam menetapkan sukubunga, juga diupengaruhi oleh berbagai kebijaksanaan, khususnya yang dikeluarkan oleh Depantemen Keuangan dan Bank Sentral.

3. Persaingan

Persaingan antar bank juga merupakan faktor yang dapat mempengaruhi bagi sebuah bank komersial dalam menetapkan tingkat sukubunganya, artinya jangan sampai sukubunga yang ditawarkan oleh bank tersebut kalah bersaing dengan bank lain. Oleh 
karena itu, bank harus terus menerus memantau bagaimana dan berapa besár sukubunga yang ditawarkan oleh pesaing, sehingga bank yang bersangkutan bisa mematok sukubunga yang lebih efektif, tepat, menarik, dan menguntungkan baik. bagi masyarakat maupun bagi bank itu sendiri. Semakin sedikit pesaing yang dihadapi, biasanya akan semakin mudah mengantisipasinya. Tingkat bunga di sini tidak hanya untuk deposito saja, tetapi juga berlaku terhadap sukubunga kredit yang ditawarkan.

\section{Jangka waktu}

Sebagaimana diketahui bahwa bunga adalah upah karena adanya penggunaan uang oleh penyimpannya. Bunga ini biasanya dinyatakan dalam prosentase dari jumlah pokoknya dan dihitung dengan dasar tahunan.

Dalam hubungannya dengan deposito berjangka misalnya, bunga itu adalah balas jasa bank terhadap deposan yang telah menyimpan uangnya di bank, dimana semakin lama jangka waktu simpanan, maka akan semakin tinggi pula bunga yang akan diperoleh :deposan, karena adanyă penggunạan uang tersebut oleh bank dalam jangka waktu yang lama pula. Namun keadaan semacam itu berlaku dengan asumsi tertentu yakni keadaan ekonomi yang sedang bertumbuh. Sebab jika kondisi ekonomi berubah seringkali bank-pun mengubah sukubunganya sesuai dengan kondisi ekonomi dalam jangka waktu tertentu. Oleh karena itu faktor jangka waktu dalam menetapkan tingkat bunga tidaklah mutlak, artinya belum tentu dalam jangka waktu yang lebih panjang deposito akan memperoleh imbalan bunga yang lebih tinggi, karena juga bergantung pada aspek serta kondisi perekonomian dan keadaan intern bank itu sendiri.

Selain faktor-faktor, ekstern perbankan, tingkat bunga juga dipengaruhi oleh intem perbankan itu sendiri. Faktorfaktor intem tersebut adalah :

\section{Komposisi dana bank}

Pada dasamya dana-dana bank berasal dari pihak ketiga yang dihimpun melalui bermacam produk lainnya. Beradasar hal tersebut bank juga harus memperhatikan tingkat harga (sukubunga) untuk masing-masing jenis produk agar komposisi bank dalam sisi pendanaan bisa harmonis, yakni untuk menentukan berapa persen target pada dana deposito, berapa persen tabungan, dan lain-lainnya. Oleh karena itu sebelum bank menetapkan' suku bunganya yang paling pas, misalnya untuk deposito berjangka, bank terlebih dulu harus mencermati sukubunga pada produkproduk lainnya dalam rangka merancang suatu komposisi dana yang paling efektif.

2. Kebutuhan dana bank

Pengertian kebutuhan dana bank disini menunjukkan kondisi likuiditas bank yang bersangkutan. Misalnya bank kekurangan dana dalam jangka pendek, maka bank dapat menawarkan suku bunga deposito yang lebih tinggi untuk deposito bérjangka dengan janga waktu pendek. Demikian sebaliknya, yakni jika bank tengah kelebihan 
likuiditas, maka ia akan memberlakukan tingkat suku bunga deposito yang lebih rendah agar arus dana deposito bisa diperkecil atau menurunkan sukubunga kredit agar kelebihan dana tersebut bisa segera tersalurkan. Hal ini tentunya disesuaikan benar dengan kondisi likuiditas bank yang bersangkutan.

\section{Kebijaksanaan intern bank}

Maksudnya adalah tentang kebijaksanaan yang diterapkan pada suatu bank yang berhubungan dengan penentuan tingkat suku bunga. Misalkan, untuk bank yang baru berdiri biasanya akan menawarkan tingkat sukubunga yang lebih.menarik dibanding dengan bank pesaing, dalam rangka penetrasi pasar, yakni merebut simpati masyarakat agar mau menjadi nasabah dalam arti mau menyimpan uangnya di sana atau meminjam uang.

4. Tingkat efisiensi bank

Efisiensi yang dimaksud di sini adalah kemampuan bank dalam mengelola dananya, sehingga biaya yang dikeluarkan oleh bank tidaklah terlalu besar. Artinya jika bank mampu melakukan kegiatan secara profesional, maka dapat menekan suku bunga depositonya lebih rendah, maka sukubunga kredit yang akan diberikan juga bisa diperkecil. Efisiensi bank ini juga menyangkut pengelolaan sumber daya manusia, sebab biaya yang ditimbulkan oleh sumberdaya tersebut nantinya juga akan diperhitungkan dalam penentuan suku bunga kredit sebagai biaya overhead.

\section{Implikasi RAPBN Terhadap Sukubunga}

Seperti telah disebutkan diatas bahiwa RAPBN tahun 1992/1993 merupakan anggaran yang bersifat kontraksi, maksudnya tidak mengarah pada perluasan investasi tetapi malah bersifat menciutkan. Hal ini terlihat dengan adanya kenaikan RAPBN yang secara rill sangat kecil. Secara absolut memang kenaikan RAPBN tahun ini dibanding dengan APBN tahun 1991/19'92 sebesar $11 \%$. Namun kenaikan ini bila dikaitkan dengan tingkat inflasi yang mungkin bakal terjadi pada tahun anggaran 1992/1993 akan sangat kecil. Bila diasumsikan tingkat inflasi yang terjadi sama dengan tahun lalu sebesar 9,5 \%, maka kenaikan riil RAPBN 1992/1993 adalah sebesar $1,5 \%$.

Indikator lain yang menunjukkan bahwa RAPBN adalah bersifat kontraktif adalah lebih besamya dana yang diserap perekonomian dibanding dengan yang dialokasikan kembali dalam perekonomian. Dengan menghitung selisih dana yang dikeluarkan dari perekonomian yang berupa penerimaan dalam negeri dari sektor non migas terhadap pengeluaran rutin 'dikurangi pengeluaran. untuk pembayaran kembali utang luar negeri berikut bunganya ditambah pengeluaran pembangunan (melalui pembayaran rupiah sebagai dana yang dialokasikan ke dalam perekonomian), temyata terjadi kelebihan penyerapan sebesar $\mathrm{Rp}$ 1,5 trilyun, suatu jumlah yang sangat berarti tentunya. Kita lihat pada RAPBN tahun 1992/1993 bahwà penerimaan dalam negeri dari sektor non migas sebesar $\mathrm{Rp} 32,6$ trilyun sedangkan pengeluaran rutin tercatat sebesar Rp 33,2 trilyun. Pengeluaran untuk pembayaran' utang luar 'negeri berikut bunganya sebesar Rp 15,9 trilyun 
dan pengeluaran' pembangunan pembayaran rupiah sebesar Rp 13,8 trilyun.

Dengan perhitungan yang sama, APBN tahun 1991/1992 masih ada ekspansi sebesar Rp 2,2 trilyun. Sehingga tidak heran bila pada tahun tersebut walaupun ada kebijakasanaan uang ketat atau tigh money policy dunia usáha masih bisa berjalan, meskipun hanya yang berskala besar, sedang yang menengah ke bawah banyak yang gulung tikar.

RAPBN tahun 1992/1993 yang. kontraksi ini juga disebabkan misi politik pemerintah, yakni untuk memacu kemandirian atas pembiayaan pembangunan guna. menegakkan dan mempertahankan kedaulatan negara dan bangsa dari kemungkinan campur tangan atau rekayasa pihak asing terhadap masalah dalam negeri. Cara yang digunakan untuk tujuan politik tersebut adalah dengan melalui pengurangan penerimaan pembangunan berupa utang luar negeri. Hal ini memang sangat berkaitan dengan adanya kasus Dili yang terjadi pada tanggal 12 Nopember tahun lalu. Gema kasus Dili memang cukup besar, terbukti dengan banyaknya negaranegara yang tergabung dalam IGGI akan mengurangi atau bahkan akan menghentikan sama sekali bantuannya. Untuk menaikkan gengsi politik itulah maka pemerintah berkehendak untuk segera bisa mandiri dengan jalan mengurangi anggarannya melalui pengurangan utang luar negeri.

Di samping itu untuk menunjukkan gengsi ekonomi dihadapkan para donor (pemberi bantuan) seperti IGGI, Word Bank, dan IMF pemerintah mewujudkannya dengan meningkatkan pengeluaran untuk pembayaran utang luar negeri termasuk bunganya. Pengeluaran untuk pos ini pada anggaran tahun ini melonjak menjadi $R p$ ' 15,9 trilyun atau naik $10,6 \%$ dibanding tahun lalu.

Dengan adanya anggaran, yang bersifat kontraksi ini, maka implikasinya adalah kesulitan mencai dana bagi para investor, sehingga harga uang atau dana semakin mahal. Kondisi ini yang bisa memaksa kalangan perbankan harus menetapkan suku bunga lebih tinggi.

\section{Sektor Pajak}

Seperti diungkapkan di atas bahwa dalam. RAPBN tahun 1992/1993 pemerintah bertekad untuk memacu kemandirian atas pembiayaan pembangunan, sehingga menurunkan anggaran penerimaan pembangunan atau utang luar. negeri. Dengan menurunnya penerimaan utang luar negeri, berarti pemerintah harus mencari sumber dana lain untuk menutup kenaikan anggaran tahun ini. Dan sektor yang dijadikan sasaran adalah dari pajak. Penerimaan dari pajak ini dianggarkan sebesar Rp 28,8 trilyun atau naik sekitar $29 \%$ dibanding tahun sebelumnya. Dari penerimaan tersebut, kenaikan lebih banyak ditekankan pada pajak penghasilan (PPh) dan pajak pertambahan nilai (PPN). PPh diperkirakan naik dari Rp 8 trilyun menjadi Rp 10,9 trilyun atau $36,3 \%$.

Salah satu renovasi kebijaksanaan yang diambil oleh pemerintah dalam rangka memacu penerimaan sektor pajak ini adalah dengan mengubah peraturan perpajakan tentang pajak penghasilan $(\mathrm{PPh})$ atau bunga deposito. Peraturan PPh atas bunga deposito tersebut tertuang dalam peraturan perpajakan PP No. 74/1991 yang dikeluarkan tanggal 31 Desember 1991. Peraturan làma, tarif $\mathrm{PPh}$ atas bunga deposito dikenakan tarif sama 
sebesar $15 \%$, Sedangkan peraturan yang baru tarif PPh diberlakukan secara progresif terhadap deposan badan akan dikenai pajak sama seperti $P P h$ perseroan, maksudnya penghasilan bunga deposito dari perusahaan akan dikenai tarif $15 \%$ untuk nilai 10 juta ke bawah, Rp 10 juta dikenakan tarif $25 \%$ sedang sisanya di atas Rp 50 juta akan dikenakan tàrif $35 \%$.

Dengan perubahan tarif pajak atas bunga deposito tersebut, tentunya akan menghambat kalangan pérbankan dalam memobilisasi dana masyarakat terutama dari perusahaan. Karena dèngan adanya kenaikan tarif pajak, berarti uang yang diterima juga menjadi kecil atau retum yang didapat akan menurun. Bagi kalangan perusahaan, apabila retunnya dianggap kurang memadai ada kemungkinan untuk menarik dananya yang disimpan di bank. Apabila banyak kalangan pengusaha menarik dananya dari bank, bisa mengakibatkan bank-bank mengalami kesulitan likuiditas. Untuk memperoleh dana dalam, keadaan kekurangan likuiditas, jalan yang lebih mudah ditempuh oleh bank adalah dengan menaikkan sukubunga, agar para deposan tidak lari atau menarik dananya.

Dengan kondisi yang demikian ditambah masih cukup ketatnya Bank Sentral mengucurkan kredit likuiditasnya, maka sukubunga akan kembali naik.

Seperti tersebut di atas bahwa yang mempengaruhi kecilnya sukubunga ada beberapa hal, bisa berasal dari faktor ekstemal maupun intemal bank. RAPBN sebagai salah satu faktor ekstemal bank, bagaimanapun telah mempengaruhi para bankir dalam menetapkan besamya suku bunga. Faktor eksternal lain yang juga mempengaruhi sukubunga adalah. kebijaksanaan pemerintah untuk mengendalikan pinjaman komersial luar negeri atau offshor loan yang tertuang dalam Keppres No. 39 tahun 1991. Dengan pengaturan tersebut, perbankan tidak bebas lagi meminjam dana dari luar negeri yang sukubunga relatif sangat murah dibanding sukubunga dalam negeri. Kalau kita tengok ke depan, bahwa pada saat pemerintah mengeluarkan kebijaksanaan uang ketat, secara teoritis seharusnya akan menyebabkan gairah investasi juga menurun, sebảb dengan sulitnya didapatkan uang tunai, maka akan berakibat sukubunga tinggi, namun kenyataannya gairah investasi terutama bagi para pengusaha kuat tetap bertahan. Temyata pihak perbankan yang besar maupun pengusaha kuat berusaha memenuhi dana investasinya dari pinjaman luar negeri atau Offshore loan. Kita lihat tabel di bawah ini :

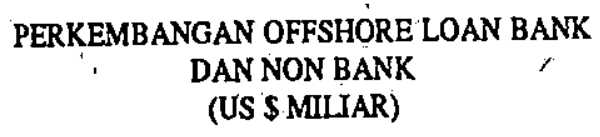

PERKEMBANGAN OFFSHORE LOAN BANK DAN NON BANK (US \$ MILIAR)

\begin{tabular}{lrrr}
\hline LEMBAGA & $1988 / 89$ & $1989 / 90$ & $1990 / 91$ \\
\hline Bank & 0,38 & 2,17 & 6,85 \\
Non Bank & 12,06 & 12,07 & 13,84 \\
\hline
\end{tabular}

Sumber : Warta Ekonomi, 16 September 1991

Dari tabel tersebut kita lihat bahwa perkembangan jumlah offshore loan dari perbankan 'sangat mencolok, sehingga pada tahun 1990/1991 saat kebijaksanaan yang ketat dilakasnakan, temyata pihak perbankan banyak yang mengambil kredit dari luár negeri. Dengan demikian bunga kredit yảng seharusnya tinggi menjadi cukup rendah. Namun sayangnya, perluasan kredit dari bank-bank tersebut 
hanyalah terbatas pada nasabah kelompoknya ataupun pada kelompokkelompok perusahaan besar. Akibatnya yang terlihat adalah sukubunga kredit sangat tinggi untuk kalangan pengusaha menengah dan swasta. Demikian pula dengan bank-bank yang relatif kecil dan bank non devisa, mereka mengalami kesulitan dana. Keterbatasan tersebut mengharuskan perbankan yang relatif kecil menggunakan dana dalam negeri yang sangat mahal, sehingga tentu saja sukubunga yang ditetapkan' juga menjadi mahal.

Persaingan antar bank sejak dikeluarkan paket deregulasi 27 Oktober 1988 (Pakto) menjadi semakin tajam. Dengan Pakto tersebut, banyak bank yang membuka kantor-kantor cabang yang hampir di seluruh nusantara. Bank-bank baru banyak yang bermunculan, sehingga mau tidak mau mereka berebut nasabah. Untuk bersaing tersebut menaikkan sukubunga merupakan alternatif yang menarik bagi bankir selain pemberian hadiah.

\section{Faktor Internal}

Kalau kita tengok tengok lebih jauh mengenai dunia perbankan.Indonesia saat ini, nampak cukup memprihatinkan. Setelah didera oleh kebijaksanaan uang ketat oleh pemerintah dan gebrakan sumarlin, saat ini perbankan mengalami beberapa permasalahan intem yang serius.

Pertama, menumpuknya kredit macet yang cukup tinggi yakni sebesar 3,4 \% dari total kredit yang disalurkan perbankan atau sekitar Rp 4,64 trilyun. Besarnya angka kredit macet ini mengakibatkan perbankan semakin selektif dalam memberikan kreditnya kepada nasabah. Hanya nasabah yang mempunyai reputasi bisnis yang baik dan mampu membayar bunga cukup tinggi yang direalisasikan. kreditnya. Hal ini dilakukan demi mengurangi resiko kredit macet dan sekaligus berusaha. menutupnya dengan menaikkan sukubunganya.

Kedua, saat ini perbankan juga harus menyediakan dana untuk memenuhi ratio kecukupan modal atau capital adequacy. ratio $(C A R)$, sesuai dengan paket Februari yang mengharuskan bank. mempunyai CAR sebesar $8 \%$. CAR sebesar- $8 \%$. ini mengacu pada ketentuan perbankan internasional yakni aturan pada Bank for International Settlement (BIS) dengan maksud agar bank-bank di Indonesia dinilai sehat dan bisa bersaing di pasar intemasional. Kecukupan modal tersebut harus dipenuhi secara bertahap, yakni $5 \%$ paling lambat tanggal 31 Maret 1992 dan sudah harus mencapai $8 \%$ pada tanggal 31 Desember 1993. Bagi bank yang CARnya belum mencukupi sampai saat ini, maka ketentuan tersebut akan memaksa mereka untuk mencari tambahan modal atau alternatif lainnya. Uniknya yang paling parah kondisi CARnya adalah bank pemerintah, yang sampai saat ini sebenamya sebagai Leader Bank. Berarti apabila bank pemerintah menetapkan sukubunga tinggi, maka bank-bank swasta lainnya akan mengekor di bélakangnya. Untuk mencukupi permodalan tersebut, apabila tidak bisa menambah dana masyarakat modal dari pemilik, maka mereka akan berusaha untuk menahan dana masyarakat atau dana masyarakat tidak, disalurkan sebagai kredit. Penghentian kredit ini mengakibatkan dana yang dibutuhkan masyarakat tidak bisa dipenuhi, maka apabila permintaan akan dana lebih besar, bunga akan meningkat.

Di samping itu masalah yang juga 
cukup mengkhawatirkan perbankan selain ketentuan kecukupan modal (CAR) adalah pembatasan Loan to deposit Ratio (LDR). LDR menunjukkan seberapa jauh dana yang diberikan sebagai kredit dibiayai oleh dana yang dihimpun dari masyarakat. Kalau kita tengok LDR dari beberapa bank terutama bank pemerintah, LDR-nya ada yang mencapai $400 \%$ yakni Bank Tabungan Negara yang mencapai $458 \%$, Bapindo $585 \%$ dan bank-bank pemerintah lain yang minimal mereka mempunyai LDR mencapai $120 \%$. Padahal dalam peraturan Bank Sentral LDR maksimal adalah sebesar $1.10 \%$.

Memang dengan LDR yang besar berarti banyak dana masyarakat yanig diberikan, sebagai kredit, sehingga profitabilitas akan meningkat, tetapi likuiditasnya juga sangat memprihatinkan. Untuk menurunkan LDR ini berarti harus menurunkan jumlah kredit, sehingga para pengusaha akan kesulitan mencari dana. Hal ini yang akan mengakibatkan kenaikan sukubunga.

Ketiga, kondisi bank saat ini terutama bank pemerintah, mengarah pada inefisiensi. Inefișiensi ini bisa dilihat dengan adanya beberapa bank baik swasta maupun pemerintah yang melakukan pemutusan hubungan kerja. -Alasan yang utama memang karena kurang efisien. Dengan kurang efisiennya perbankan, maka banyak terjadi pemborosanpemborosan. Biaya akibat inefisiensi ini tentunya harus diperhitungkan. Perhitungannya tentunya harus dimasukkan ke dalam unsur sukubunga.

\section{Kesimpulan}

dari uraian di atas dapat disimpulkan bahwa RAPBN 1992/1993 yang mempunyai .sifat kontraksi. yang diakibatkan oleh kemauan pemerintah untuk mendukung tujụan politik dan menaikkan gengsi ekonomi di mata negara donor, bagaimanapun telah mempengaruhi para bankir dalam menetapkan sukubunga. Apalagi pemerintah dalam menutup kekurangan anggaran pembangunan dengan meningkatkan pajak terutama merubah tarif pajak yang berhubungan dengan perbankản, yakni pajak penghasilan atas bunga deposito, maka secara pasti para pengelola bank akan menyesuaikan deposan dengan cara menaikkan sukubunganya.

Kenaikan suku bunga selain faktorfaktor tersebut di atas, juga didukung oleh kebijaksanaan pemerintah yang lain, seperti peraturan pinjaman komersial luar negeri, paket deregulasi 28 Februari 1991, maupun pengetatan likuiditas. Dari pihak intern lembaga perbankan sendiri juga masih mengalami beberapa permasalahan yang mengakibatkan sulitnya untuk menurunkań sukubunga.

\section{DAFTAR PUSTAKA}

InfoBank, Majalah Bulanan, No. 146, Vol XV. Februari 1992.

Lampiran pidato Presiden Suharto tanggal 6 Januari 1992

Masassya, Evielyn G., Menyingkap Tabir Suku Bunga Deposito, Harian Media Indonesia 6 Januari 1992, Jakarta, h. 4-9

Merdeka, Harian, k.4, h. 4-9

Mulyono, Teguh Pojo,. Manajemen Kredit bagi Bank Komersial, BPFE, Yogyakarta, 1987

Nopirin, Ekonomi International, ed 2, BPFE, Yogyakarta, 1990

Sinungan, Muchdarsyah., KREDIT : Seluk Beluk dan Teknik Pengelolaan, Yagrat, Jakarta, 1980

Sutrisno, PPh Bunga Deposito dan Implikasinya, Harian Manutung, Yagrat 17 Februari 1992, Balikpapan, h.6

-.---., Mungkinkan Suku Bunga turun ?, Harian Wawasan 2 Januari 1992, h. 2

Wijaya, Faried., Ekonomika Makro, Femoza dan Fakultas Ekonomi UMS, 1989. 